\title{
Design of a 25MWe Solar Thermal Power Plant in Iran with Using Parabolic Trough Collectors and a Two-Tank Molten Salt Storage System
}

\author{
Aidin Alinezhad Kordmahaleh, ${ }^{1}$ Mohammad Naghashzadegan, ${ }^{2}$ Kourosh Javaherdeh, ${ }^{2}$ and \\ Mohammadreza Khoshgoftar ${ }^{2}$ \\ ${ }^{1}$ Department of Intelligent Hydraulics and Automation, Tampere University of Technology, Tampere, Finland \\ ${ }^{2}$ Department of Mechanical Engineering, Faculty of Engineering, University of Guilan, Rasht, Iran \\ Correspondence should be addressed to Mohammad Naghashzadegan; naghash@guilan.ac.ir
}

Received 4 May 2017; Revised 4 August 2017; Accepted 22 August 2017; Published 22 November 2017

Academic Editor: Philippe Poggi

Copyright (c) 2017 Aidin Alinezhad Kordmahaleh et al. This is an open access article distributed under the Creative Commons Attribution License, which permits unrestricted use, distribution, and reproduction in any medium, provided the original work is properly cited.

\begin{abstract}
Nowadays, parabolic trough solar thermal plants are prevalent around the world. In different areas concerning the amount of solar radiation, their standard size is approximately between 20 and 100 MWe. Certainly, the right size of the solar field is the first selection with regard to nominal electrical power. A vast area will be economically unreasonable whereas a small area will mainly cause the power plant to operate at the part-load condition. This paper presents an economic modeling of a solar parabolic trough plant, operating at $25 \mathrm{MWe}$ in Yazd, Iran. The varying types of collector dimensions have been investigated; then, by selecting autumnal equinox (22 September) at 12:00 PM as the design point, thermal performance of the solar power plant has been featured annually, in all conditions. The total operating time of the power plant is about 1726 hours (1248 hours in full-load condition). In the end, the effect of thermal storage tanks has been analyzed to save extra solar heat and use it at nights in hot months. By implementing a storage system, the total operating time will be increased to 3169 hours (2785 in fullload condition). Moreover, $7974 \mathrm{GJ}$ useful thermal energy can be obtained from the solar field and storage system.
\end{abstract}

\section{Introduction}

Nowadays, the global warming and green gas effect are the most important hazards for the Earth's future. It seems that the optimum solution is using renewable energy resources to stop their adverse influences on human life. The solar resource has been taken into account in several researches as the most extensive resource since the last decades [1]. Parabolic trough technology has demonstrated the truth of being the most fully grown and of having minimum expense in solar thermal technology [2]. Solar parabolic trough collectors are efficiently employed for high temperature $\left(300-400^{\circ} \mathrm{C}\right)$ without any serious degradation in efficiency. Consequently, most of the construction projects of trade solar power plants are focused on this kind of collectors; some parabolic trough power plants are planned to be built in USA, Spain, and Middle East [3]. They contain a solar field, a steam generator, a Rankine cycle, and a fossil fuel (backup) system [4].

Although a thermal storage system was not used very often in ancient parabolic trough plants (some exceptions such as Andasol-1 in Spain) [5], today, the storage system is considered an essential section because in some region like Nevada, only $2 \%$ of fossil fuel hybridization is permitted to reduce the transient effects [6]. With no doubt, the next parabolic trough plants will contain storage systems because the schedule of hourly operation can be programmed automatically [1].

To keep oil temperature higher than the minimum range, fossil fuel hybridization is commonly done by an oil heater. Another system that operates during the night and extended noninsolation period is a fossil fuel that fired the boiler to 


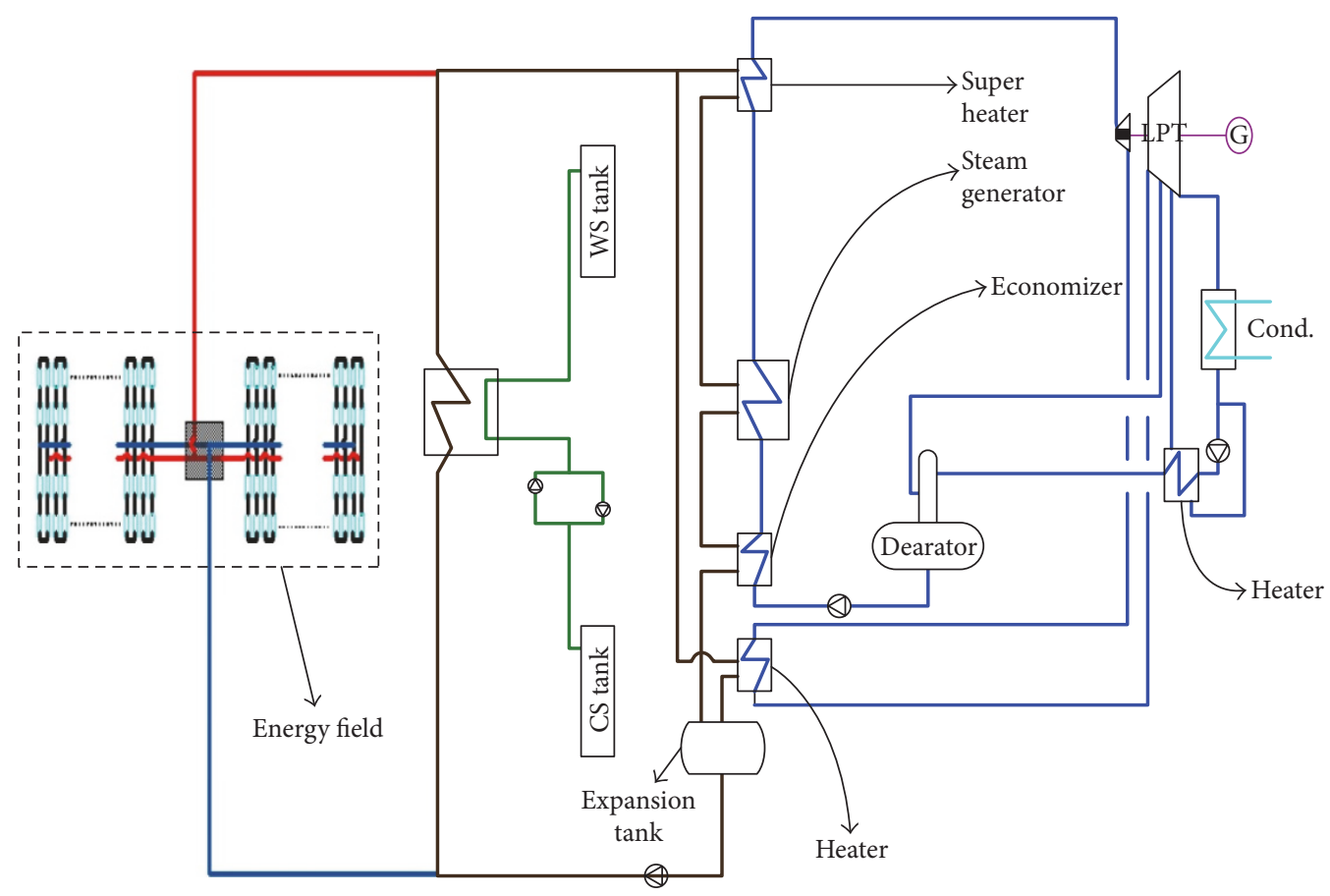

Figure 1: Diagram of the solar power plant.

originate steam for turbine seals. In a solar power plant, the usual heat transfer fluid (HTF) is oil that operates as an intermediate object between the power cycle and solar field [7].

As it was noted, Middle East is a favorite place from the viewpoint of solar radiation. In this specific area, Iran has some more favorable characteristics for installing a solar power plant like having the hot and dry weather for a couple of months in sunny periods, which results in the high rate of air cleanliness, especially in the central region. Therefore, Yazd city, which is in the center of Iran and near two wildernesses, has been selected [8]. Due to economic issues and proportion of solar radiation in Iran, the nominal electrical power has been assumed to be $25 \mathrm{MWe}$.

The model, implemented in this article, contains a choice of the design point of the power plant wherein the power plant should operate at nominal power just with solar energy. Because the storage system would be included in this research, therefore, the design point should be chosen among some days which have moderate solar radiation. It causes extra received thermal energy for storage in sunny periods. Then, the number and length of collectors (trough length) will be optimized, and next, the thermal performance of the solar field will be analyzed annually. Mass flow, received solar power, and efficiency of collectors are the three key features of a solar field that will be calculated in several sunny months. At the end, a heat storage system (two tanks of molten salt) has been taken into account to improve the operating hours of the power plant.

\section{Identifying Solar Field Parameters at the Design Point}

2.1. Power Steam Cycle (Rankine). As it was mentioned, the power plant operates at $25 \mathrm{MWe}$. Experimentally, four generative heat feeders are responsible for this power. There are also a low-pressure closed feedwater heater, a deaerator, an economizer, a steam generator, and a super heater in the Rankine cycle (Figure 1).

The power cycle has been assumed to perform at full load even when there is not enough solar thermal power. In this situation, a storage tank or fossil fuel must cover the shortage of power. The kind of fluid for heat transfer in the solar field and its temperature fluctuations determine the inlet temperature of steam to the turbine.

The conventional oil which is used in the solar power plant is Therminol VP-1 due to its steadiness up to operating temperature of $400^{\circ} \mathrm{C}$. Ordinarily, the highest steam temperature is around $370^{\circ} \mathrm{C}$ in the Rankine cycle.

$25 \mathrm{MWe}$ nominal power shows the electrical energy which is produced by a steam generator. Apparently, a solar field should provide more thermal power for the steam Rankine cycle which is the typical cycle of a solar power plant. The efficiency of the Rankine cycle depending on cycle characteristics is between $33 \%$ and $40 \%$ [9]. In this research, it was assumed that the pipes which are outside of the solar field are not insulated. Indeed, the electrical power of pumps, operating in the energy field and storage tank section, should be supplied by the Rankine cycle. As a result, the Rankine cycle efficiency has been assigned to be $27.8 \%$, and the solar energy field should provide 90MWth.

\subsection{Arrangement and Performance of the Solar Field at the Design Day}

2.2.1. Design Point Condition. Obviously, the solar radiation varies by changing of seasons. For designing the power plant, the noon of one particular day should be assigned as the design point so that the power plant can operate without a 


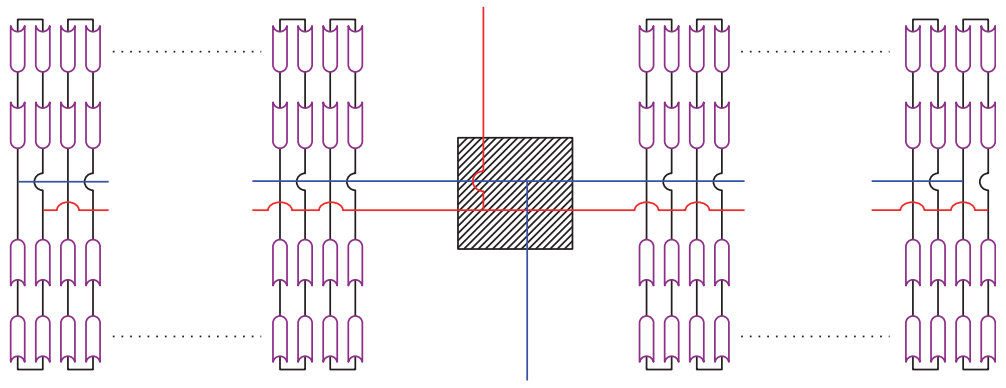

FIgURE 2: Collector loop configuration in the solar field.

fuel system backup. Yazd city is located at $31.89^{\circ} \mathrm{N}$ latitude which is between the tropic of cancer and Arctic Circle. In this imaginary belt, the insolation (incoming solar radiation) has the maximum amount at the June solstice day [10]. Due to the existing storage system, the noon of autumnal equinox (22 September) has been selected as the design point. It leads to the systems to receive more solar energy in sunny periods, stored in the storage tank.

Axis orientation of a collector can be N-S or E-W. In E$\mathrm{W}$ orientation, the operational performance of the collector is not balanced during one day because of large incidence angle. In this situation, the thermal efficiency of the collector reduces considerably after sunrise and before sunset hours. It results that the received solar energy in E-W orientation is lower than that in N-S orientation [11]. Therefore, in this article, the $\mathrm{N}-\mathrm{S}$ orientation with a continuous tracking system has been chosen so that solar radiation makes the minimum angle of incidence with the aperture surface all the times, and consequently, there will not be any shades on pipes in operating hours.

2.2.2. Arrangement and Simulation of the Collector Array. Collector arrays have been positioned like the current engineering layout for oil-cooled parabolic trough solar fields [6]. Each array contains four collectors, located in two parallel rows (Figure 2). It should be noted that inside the solar energy field, the surface of the pipes which connect collectors to each other has been considered an isolated surface and there is no heat loss. Table 1 shows the main geometrical and optical features of an assumed collector. It should be emphasized strongly that the main goal of this research is analyzing the assumed solar power plant performance in the area of Yazd, Iran. Therefore, collector parameters are not based on a real prototype though it tried these values to be closer to reality. Moreover, despite using classic thermal and solar modeling, the result of the research is entirely novel and reliable, and it can be the foundation of future practical investigations.

In this type of collector positioning, a number of arrays and trough length can vary from 80 to 120 arrays in step of 10 arrays and from $75 \mathrm{~m}$ to $150 \mathrm{~m}$ in step of $12.5 \mathrm{~m}$, respectively. In fixed nominal power, if the number of collector arrays increases, they can gain lower solar energy. In this study, considering 90MWth in 80 arrays, each of them can obtain $1125 \mathrm{~kW}$, and in 120 arrays, each can achieve $750 \mathrm{~kW}$.
To calculate the thermal power that collectors gain in each hour, the following trend has been offered [12]. At first, $H_{0}$, the amount of total daily radiation outside of the atmosphere layer, should be calculated as follows:

$$
\begin{aligned}
H_{0}= & \frac{24}{\pi} * 3600 * G_{\mathrm{SC}} *\left[1+0.033 \cos \left(\frac{360 n}{365}\right)\right] \\
& *\left[\cos \phi * \cos \delta * \sin \omega_{\mathrm{s}} *\left[\frac{\pi \omega_{\mathrm{s}}}{180}\right] * \sin \phi * \sin \delta\right] .
\end{aligned}
$$

The amount of total radiation inside of the atmosphere layer depends on $K_{T}$, the rate of air cleanliness that has been identified in various regions experimentally.

$$
K_{T}=\frac{H}{H_{0}} .
$$

The amount of hourly radiation outside of the atmosphere layer can be obtained by

$$
\begin{aligned}
I_{0}= & 3600 * G_{\mathrm{SC}} *\left(1+0.033 \cos \left(\frac{360 n}{365}\right)\right) \\
& *(\sin \phi * \sin \delta+\cos \phi * \cos \delta * \cos \omega), \\
I= & I_{0} *\left(\frac{H}{H_{0}}\right) *(a+b * \cos \omega),
\end{aligned}
$$

where $I$ is the amount of hourly radiation inside the atmosphere layer.

$$
\begin{aligned}
& a=0.409+0.501 \sin \left(\omega_{\mathrm{s}}-60\right), \\
& b=0.6609-0.467 \sin \left(\omega_{\mathrm{s}}-60\right) .
\end{aligned}
$$

Solar radiation is divided into two parts: beam radiation $\left(I_{\mathrm{b}}\right)$ and diffuse radiation $\left(I_{\mathrm{d}}\right)$. In the calculation of parabolic trough collectors, only beam radiation is necessary.

$$
\begin{aligned}
I_{\mathrm{d}} & =I *\left(A-B *\left(\frac{I}{I_{0}}\right)\right), \\
A & =0.949+0.0118 * \phi, \\
B & =1.185+0.0135 * \phi, \\
I_{\mathrm{b}} & =I-I_{\mathrm{d}} .
\end{aligned}
$$

Now if the heat loss of a collector is identified, then, the net thermal power that the collector received will be 
TABLE 1: The main geometrical and optical parameters of a collector.

\begin{tabular}{lccc}
\hline Aperture width $(\mathrm{m})$ & 6.64 & Outer dimension of a glass cover $(\mathrm{cm})$ & 7.0 \\
Inner dimension of a thermal pipe $(\mathrm{cm})$ & 3.5 & Glass cover emissivity & 0.9 \\
Outer dimension of a thermal pipe $(\mathrm{cm})$ & 4.2 & Receiver tube (pipe) emissivity & 0.2 \\
Inner dimension of a glass cover $(\mathrm{cm})$ & 6.7 & Optical efficiency & 0.8 \\
\hline
\end{tabular}

specified. Heat loss consists of convection and radiation parts [12].

$$
\begin{aligned}
q_{\mathrm{u}} & =F_{r} *\left(w-d_{\mathrm{o}}\right) * L *\left[s-\frac{U_{L}}{c}\left(T_{\mathrm{fi}}-T_{\mathrm{a}}\right)\right] \\
& =\dot{\mathrm{m}} * c p_{\mathrm{oil}} *\left(T_{\mathrm{fo}}-T_{\mathrm{fi}}\right), \\
s & =I_{\mathrm{b}} *\left(\frac{w}{w-d_{\mathrm{o}}}\right) * \eta_{\mathrm{opt}},
\end{aligned}
$$

where $q_{\mathrm{u}}$ is the useful thermal power that the collector receives by beam radiation. The heat lost and efficiency can be calculated as follows:

$$
\begin{aligned}
\frac{q_{\mathrm{l}}}{L}= & h_{\mathrm{p}-\mathrm{c}} *\left(T_{\mathrm{pm}}-T_{\mathrm{c}}\right) * \pi d_{\mathrm{o}} \\
& +\frac{\sigma \pi\left(T_{\mathrm{pm}}^{4}-T_{\mathrm{c}}^{4}\right) d_{\mathrm{o}}}{\left(1 / \varepsilon_{\mathrm{p}}\right)+\left(d_{\mathrm{o}} / d_{\mathrm{ci}}\right)\left(\left(1 / \varepsilon_{\mathrm{c}}\right)-1\right)}, \\
\frac{q_{\mathrm{l}}}{L}= & h_{w} \pi d_{\mathrm{co}} *\left(T_{\mathrm{c}}-T_{\mathrm{a}}\right)+\sigma \pi d_{\mathrm{co}} \varepsilon_{\mathrm{c}} *\left(T_{\mathrm{c}}^{4}-T_{\mathrm{sky}}^{4}\right), \\
\frac{q_{\mathrm{l}}}{L}= & \frac{U_{L}}{L} * \pi d_{\mathrm{o}} *\left(T_{\mathrm{pm}}-T_{\mathrm{a}}\right), \\
\eta & =\frac{q_{\mathrm{u}}}{I_{\mathrm{b}} * w * L} .
\end{aligned}
$$

By selection of the outlet temperature of oil in an array $\left(T_{\mathrm{fo}}\right)$, average temperature of the receiver tube (pipe) surface $\left(T_{\mathrm{pm}}\right)$, and the total heat transfer factor $\left(U_{L}\right)$ as initial assumptions and then running a trial-and-error algorithm, $q_{\mathrm{u}}$ will be obtained [12].

An operational temperature for Theminol VP-1 should be controlled in the range between 12 and $400^{\circ} \mathrm{C}$. The lower temperature causes oil freezing as well as the higher temperature of oil results in chemical reaction.

2.2.3. Effect of Mass Flow Values. Mass flow greatly affects the received solar thermal power. Because the design point has not been chosen among completely sunny days (June solstice), therefore, mass flow must not be near the maximum capacity of the system so that it can increase in sunny periods to keep oil temperature lower than $400^{\circ} \mathrm{C}$. On the other hand, this mass flow should not be meager because, at first, it causes a reduction of thermal efficiency noticeably, and then, the dimensions of the solar field will rise unreasonably to supply sufficient solar thermal power.

Based on [6], the values of mass flow have been considered experimentally between 5 and $8 \mathrm{~kg} / \mathrm{s}$ for each array. Hourly beam radiation $I_{b}$ (used in thermal calculations) and optical efficiency are equal to $607.77\left(\mathrm{~W} / \mathrm{m}^{2} \cdot \mathrm{h}\right)$ and $80 \%$,
TABLE 2: Useful thermal power $(\mathrm{kW})$ for a collector at the design point.

\begin{tabular}{lcccc}
\hline $\begin{array}{l}\text { Mass flow } \rightarrow \\
\text { Array length } \downarrow\end{array}$ & $5(\mathrm{~kg} / \mathrm{s})$ & $6(\mathrm{~kg} / \mathrm{s})$ & $7(\mathrm{~kg} / \mathrm{s})$ & $8(\mathrm{~kg} / \mathrm{s})$ \\
\hline 300 & 394.0 & 401.9 & 407.5 & 411.5 \\
350 & 452.5 & 461.8 & 470.2 & 475.6 \\
400 & 509.1 & 521.0 & 530.4 & 537.4 \\
450 & 562.5 & 578.6 & 590.2 & 598.9 \\
500 & 615.4 & 634.8 & 648.8 & 659.4 \\
550 & 666.6 & 687.9 & 704.5 & 717.1 \\
600 & 716.2 & 741.1 & 760.5 & 775.2 \\
\hline
\end{tabular}

respectively. In Table 2 , the amount of $q_{\mathrm{u}}$ for one array is illustrated in different array lengths and mass flow.

It can be observed that in the array length of $600 \mathrm{~m}$ (trough length of each collector $150 \mathrm{~m}$ ) and the mass flow range between 6 and $7 \mathrm{~kg} / \mathrm{s}$, one array can approximately provide $750 \mathrm{~kW}$, and therefore, 120 arrays of collectors (the maximum standard number according to Section 2.2.2) can supply the adequate solar energy which is needed for the nominal operation of the solar power plant at the design point. Finally, the calculated values for oil mass flow and efficiency of the collector at the design point are $6.51 \mathrm{~kg} / \mathrm{s}$ and $31 \%$, respectively.

2.2.4. Storage System. A thermal storage system provides extra thermal power for a solar power plant to produce electricity without the use of fossil fuel at noninsolation times, particularly in a peak point of demand [13]. The most progressive thermal storage system to store extra thermal power is the two-tank storage system where the same oil which circles in collectors is used in the storage system though the oil price is quite costly and its usage will substantially increase the expense of the storage system [14]. Therefore, it has been suggested to use molten salt instead of oil which can operate at high temperatures and also is very cheaper than oil. The full concept of the two-tank storage system is out of the research scope [14], and therefore, just the result of designing will be demonstrated in Section 3.3.

\section{Analysis of Annual Performance}

In this section, hourly performance will be analyzed for the solar field operation during the year. The calculations of the received thermal power, efficiencies, and trial-and-error algorithm have been carried out in MATLAB software which is one of the best mathematical tools to calculate, analyze, and 


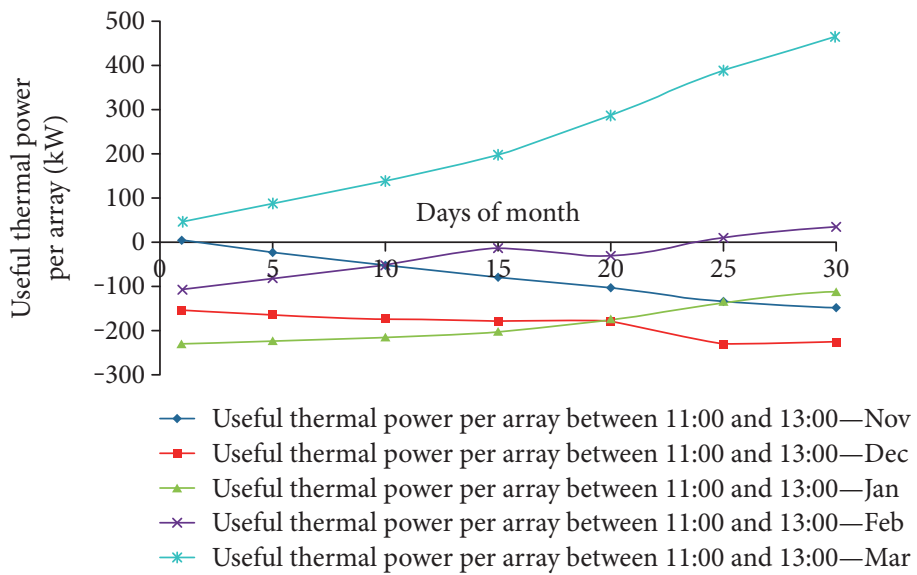

FIGURE 3: Useful thermal power per array for cold months.

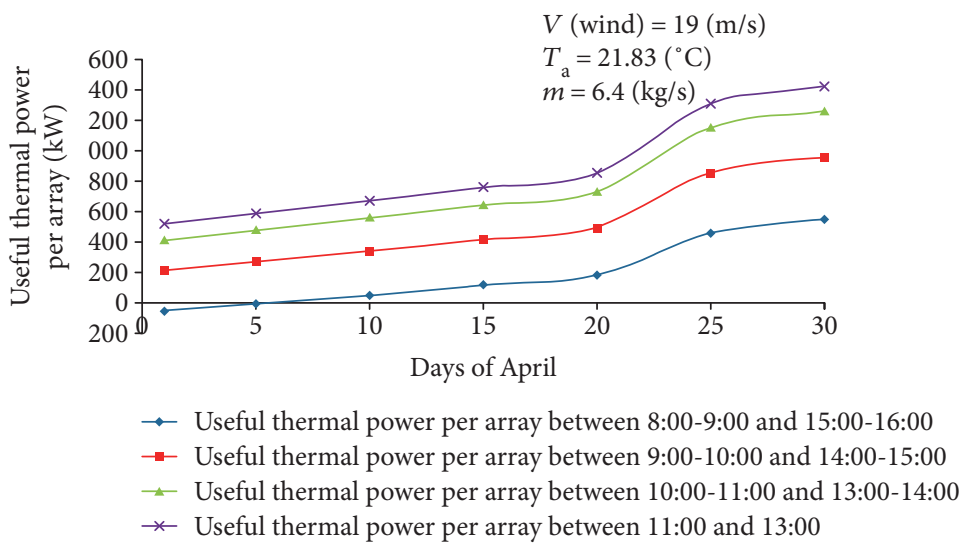

FIgURE 4: Useful thermal power per array for April.

simulate the engineering project. The following result will be represented for each month individually:

(1) The amount of useful thermal power per array which will be demonstrated in different hour ranges in fullload and part-load conditions

(2) Efficiency of array

(3) Mass flow fluctuations, especially in sunny periods, that must be increased to keep the temperature of oil in all allowable ranges

3.1. Solar Hour. Undoubtedly, solar radiation depends on the location of the sun in the sky during the day. The solar hour is introduced to make the analysis more sensible. In this definition, solar noon is a special time in the middle of sunrise and sunset, considered as 12:00 in a solar time scale whereas the local time scale is not 12:00 exactly.

3.2. Daily Analysis of the Solar Field. At first, it is assumed that the solar field begins to operate when it can supply, at least, $25 \%$ of Rankine cycle need ( $187.5 \mathrm{~kW}$ for each array). The analysis of a power plant is based on an average of hourly solar radiation. At first, the hourly solar radiation outside of the atmosphere has been calculated, and then, by considering the rate of air cleanliness, the hourly average radiation inside the atmosphere has been computed. The rates of air cleanliness are constant coefficient which was gained according to weather statistic data in the last 20 years [15].

In Figure 3, the useful thermal power per array for five months (November, December, January, February, and March) has been shown. The calculations show that, except March, the values of the useful thermal power per array are not adequate to start power plan operation. A negative value means that not only the oil temperature will not increase through passing the array but also it will lose its thermal power. Only in the 15th of March, the array gains 195.92 kW between 11:00 and 13:00 (solar time), and as a result, the solar field begins to operate in part-load condition, and for the rest of the time, fossil fuel will be needed. After the 25th of March, the operating hours of the solar field will become 4 hours (10:00-14:00 solar time).

Similarly, in Figures 4, 5, and 6, the useful thermal power per array in the next three months (April, May, and June) has been illustrated. In the 15th of April, for the first time, each array in the solar field can gain $754.6 \mathrm{~kW}$ between 11:00 and 13:00 (solar time), and it signifies that fossil fuel will not be needed in this period. From the 5th of May, the solar 


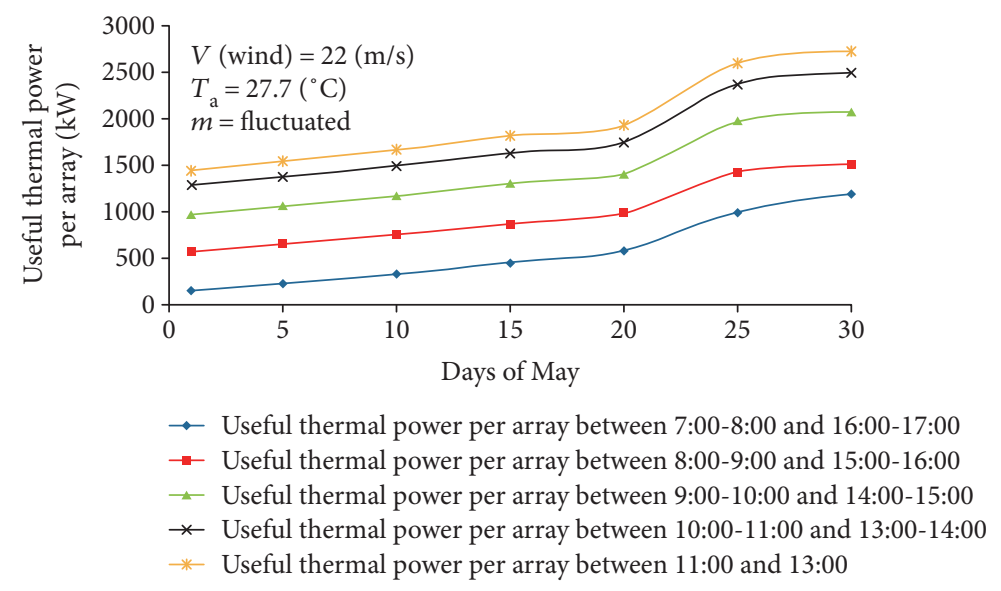

FIGURE 5: Useful thermal power per array for May.

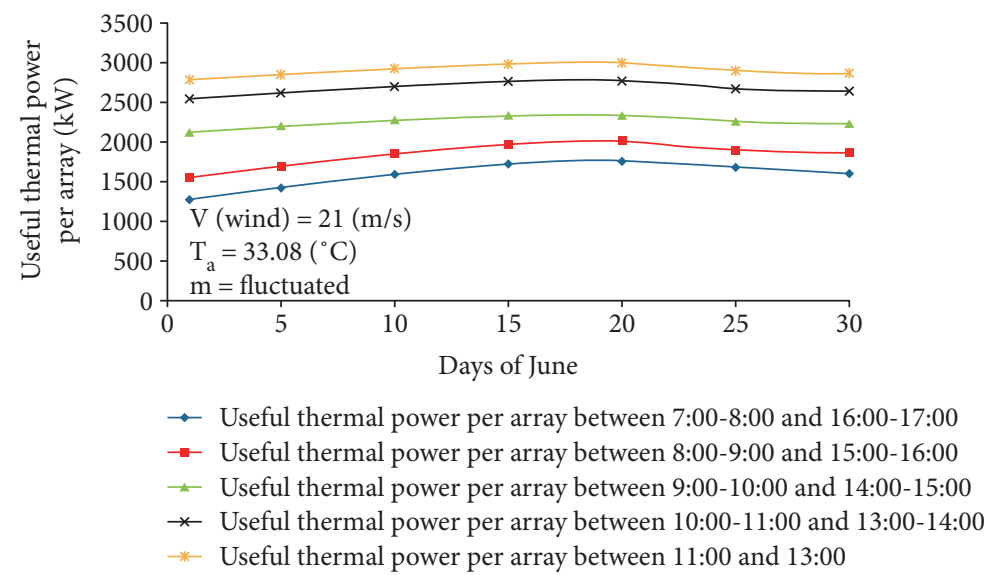

FiguRE 6: Useful thermal power per array for June.

field can work 10 hours per day, and next, after the 10th of May, full-load operating hours will be 8 hours. Finally, on the 25th of May, all 10 hours of the solar field working will be in full-load condition.

Figure 7 shows the total hours of solar field operation in part-load and full-load conditions for three months (April, May, and June). As it is observed, in June, the solar power plant operates in full-load condition without the usage of fossil fuel. Moreover, the extra thermal power will be saved in the storage tank whose analysis will be explained in Section 3.3.

In the same manner, Figures 8, 9, 10, and 11 illustrate the useful thermal power per array in four months (July, August, September, and October). Approaching the end of the sunny season, the solar radiation will naturally reduce, and collectors are expected to receive lower thermal power though the solar field will be in full-load condition continuously in July.

In the first day of August, between 7:00-8:00 and 16:0017:00 (solar time), the solar field is not able to supply enough energy, and consequently, there will be a need for fossil fuel. After the 15th of August, the working hours of the solar field have been reduced from 10 to 8 hours.

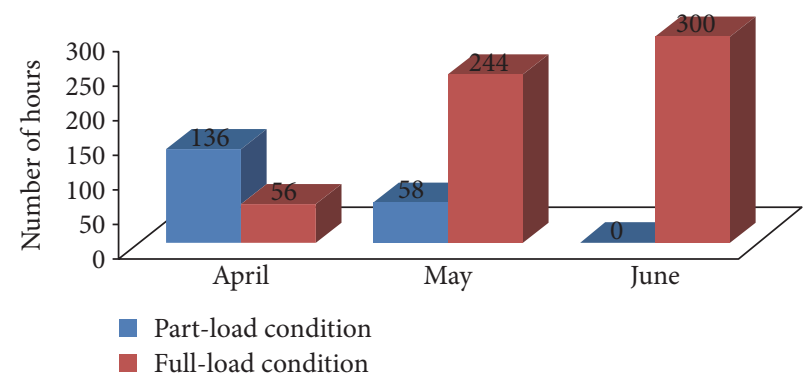

FIgURE 7: Working hours of the solar field in April, May, and June.

In September, the reduction of the solar power has the notable trend. After the 10th of September, again, operating hours of the solar field have been decreased to 6 hours, and as Figure 10 shows, from the 23rd of September, at none of the operating hours, the solar field can provide enough solar thermal power for the Rankine cycle. At the 5th and 20th of October, the operating hours will be 4 and 2 hours, respectively. Lastly, at the end of this month, the operation of the solar field will be stopped completely (Figure 11). 


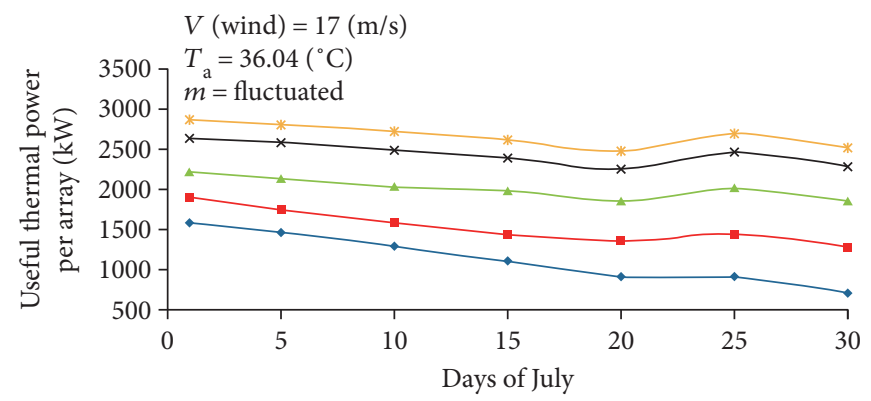

$\rightarrow$ Useful thermal power per array between 7:00-8:00 and 16:00-17:00

$\rightarrow$ Useful thermal power per array between 8:00-9:00 and 15:00-16:00

- Useful thermal power per array between 9:00-10:00 and 14:00-15:00

* Useful thermal power per array between 10:00-11:00 and 13:00-14:00

*- Useful thermal power per array between 11:00 and 13:00

FIgURE 8: Useful thermal power per array for July.

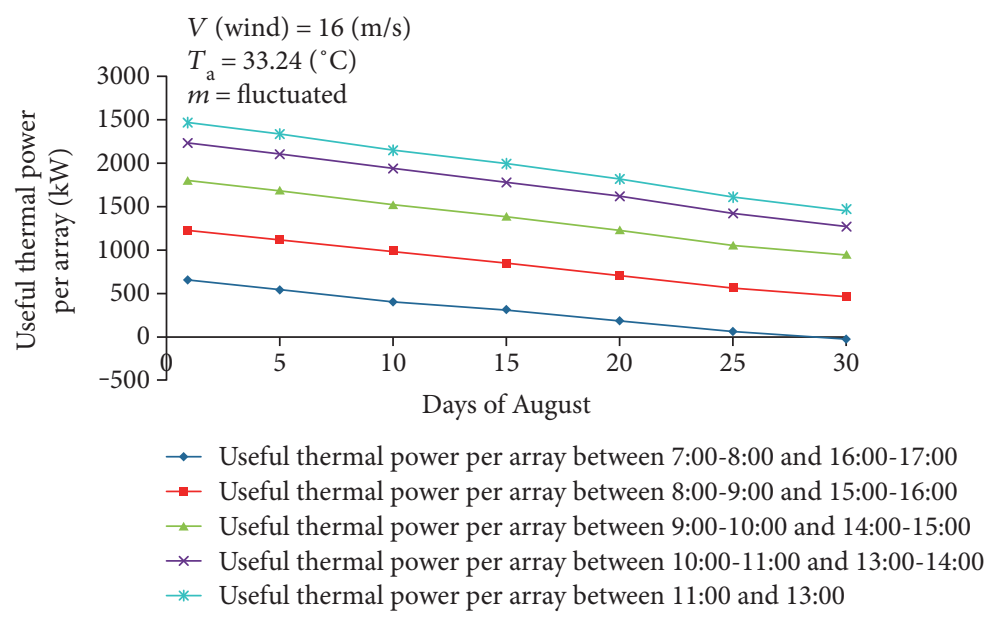

FIgURe 9: Useful thermal power per array for August.

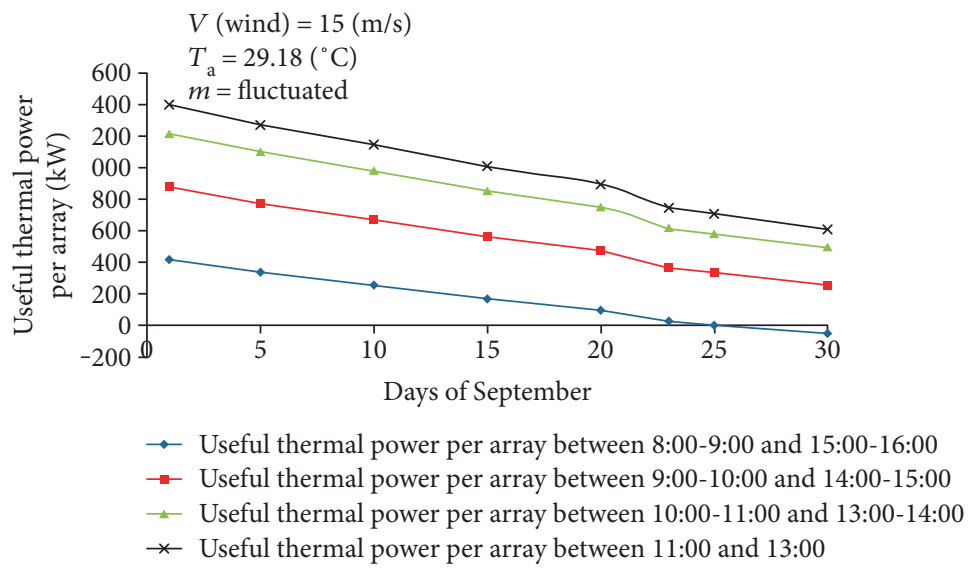

FIgURE 10: Useful thermal power per array for September.

In Figure 12, the total hours of the solar field operating in part-load and full-load conditions have been shown for four months (July, August, September, and November). In July, during the field operation (310 hours), sufficient thermal power cannot be supplied only in 4 hours. However, after July, full-load operating hours reduce steadily, and in
November (after the design point day), the solar field can only be run in part-load condition.

Figures 13 and 14 show the efficiency and the received thermal energy of the solar field, respectively. The maximum efficiency and the received solar energy belong to June approximately by $48 \%$ and 833 GJ, respectively. Finally, in 


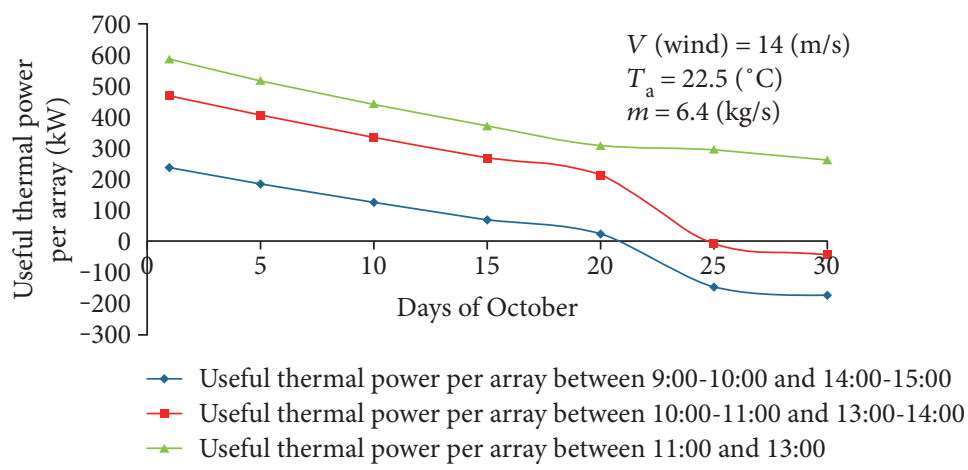

Figure 11: Useful thermal power per array for October.

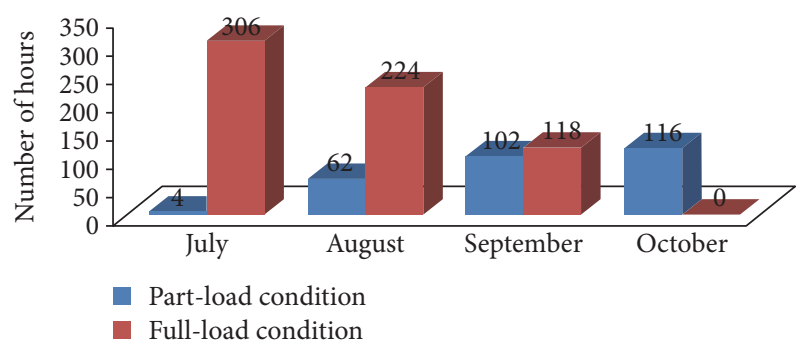

FIgURE 12: Operating hours of the solar field in July, August, September, and November.

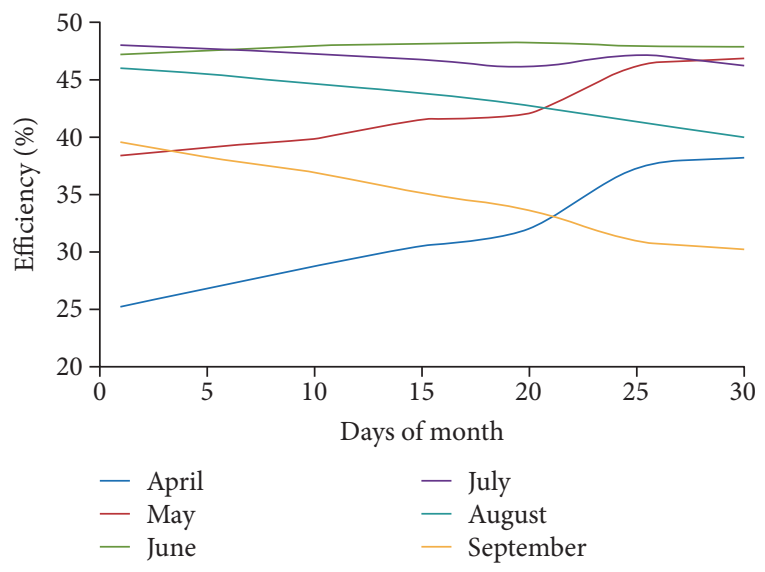

FIGURE 13: Efficiency of the solar field at sunny months.

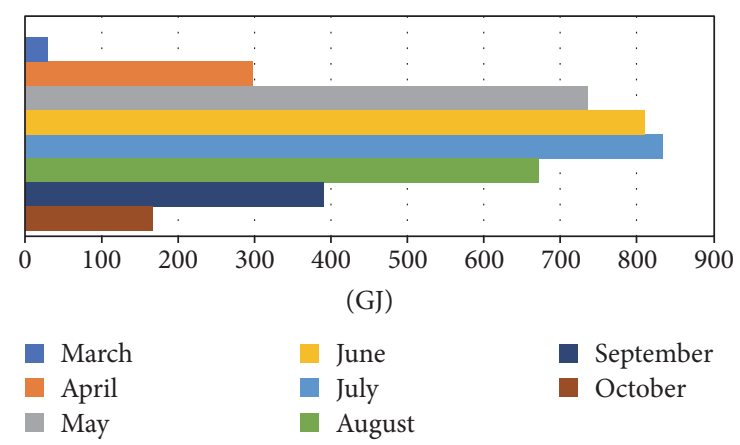

FIGURE 14: The provided thermal energy for the Rankine cycle without considering the storage system.

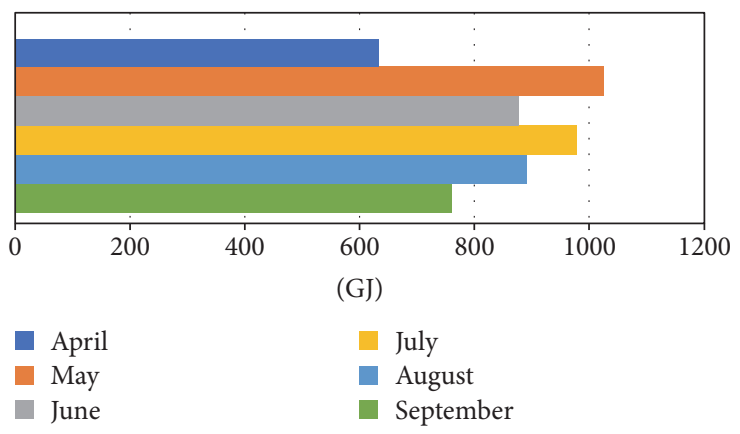

Figure 15: Heat loss in the solar field at sunny periods.

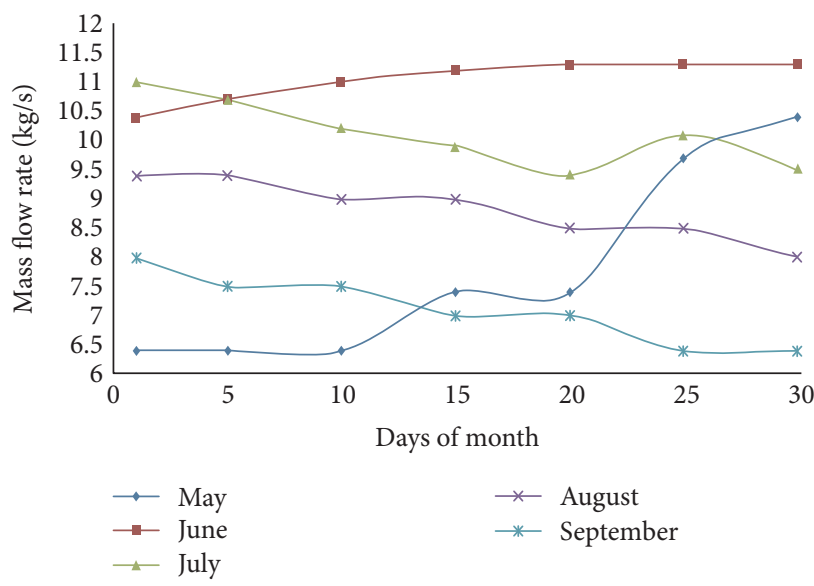

FIGURE 16: Fluctuation of oil mass flow in arrays at sunny months.

Figure 15, the heat loss result has been calculated which indicates that the utmost lost occurs in May with $1025 \mathrm{GJ}$.

Inevitably, when the solar radiations increase in sunny periods immensely, the oil mass flow must be raised to prevent chemical reaction in oil. Figure 16 expresses the fluctuation of mass flow in sunny days. The remarkable growth rate occurs in May (from 6.5 to $10.5 \mathrm{~kg} / \mathrm{s}$ ), and the maximum value will reach $11.5 \mathrm{~kg} / \mathrm{s}$ in June.

3.3. Analysis of the Storage System. To store extra thermal power in storage tanks, several heat exchangers have been used due to the massive volume of oil in the solar field. In the heat exchanger, oil will enter with various temperatures 
TABLE 3: Mass flows of molten salt at various hours at the June solstice day.

\begin{tabular}{lccccc}
\hline Solar hours at the June solstice day & $7-8 \& 16-17$ & $8-9 \& 15-16$ & $9-10 \& 14-15$ & $10-11 \& 13-14$ & $11-12$ \& 12-13 \\
Mass flow of molten salt $(\mathrm{kg} / \mathrm{s})$ & 75.39 & 83.72 & 90.78 & 98.3 & 101.67 \\
\hline
\end{tabular}

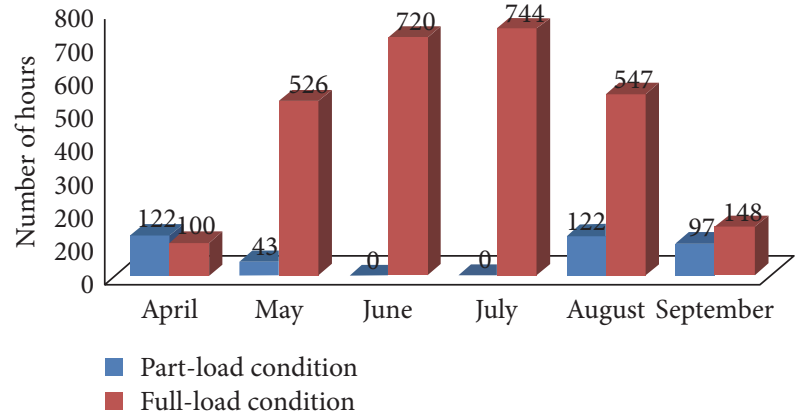

FIGURE 17: Total operating hours of the solar field with operation of the storage system.

but should exit in $290^{\circ} \mathrm{C}$ (as the assumption of oil inlet temperature in the array). Molten salt $\left(C_{p \text {,salt }}=1.6 \mathrm{~kJ} / \mathrm{kg} \cdot \mathrm{K} \&\right.$ $\rho_{\text {salt }}=1750 \mathrm{~kg} / \mathrm{m}^{3}$ ) from the cold tank pipes whose temperature is $285^{\circ} \mathrm{C}$ enters the heat exchanger, and with adjustment of its mass flow, oil outlet temperature will be set to $290^{\circ} \mathrm{C}$.

The storage tank has been designed based on the June solstice day wherein the maximum heat power is received. Table 3 shows the mass flows of molten salt which should pass through all heat exchangers in that special day which guarantee that the outlet oil temperature would be $290^{\circ} \mathrm{C}$. The calculation of the heat exchanger operation indicates that the capacity of each storage tank should be $1850.3 \mathrm{~m}^{3}(3,237,992 \mathrm{~kg}$ needed salt $)$ to store the entire extra thermal power.

In Figure 17, the total operating hours of the Rankine cycle have been presented while both the solar field and storage system are active. Differences among Figures 17, 12, and 7 obviously prove that the storage system affects significantly on a full-load period. After the 20th of April, each array receives $800 \mathrm{~kW}$ solar thermal power at noon which can be restored at noninsolation times. In the 1st of May, the solar plant is active the entire day ( 24 hours) in both part-load and full-load conditions, and finally, after the 25th of May, the solar power plant begins its full-load operations during the day.

This period of ideal operation will last about 68 days (until the end of July) in which the power plant will never need fossil fuels while it is the peak of electricity demands for cooling and air conditioning systems in industrial units and houses. It results that millions of liters of petroleum products will be economized inevitably. The provided thermal energy for the Rankine cycle by both the solar field and storage systems is demonstrated in Figure 18.

In Figure 19, the increase in operating hours has been clarified in the percentage scale. Clearly, in four months (May, June, July, and August), the effect of the storage system is undeniable, and it proves the urgency of the storage system in today's solar power plant.

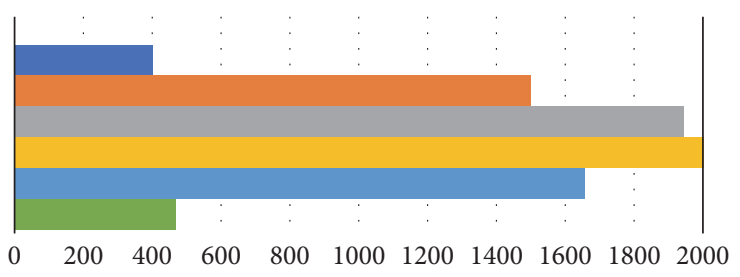

(GJ)

$\begin{array}{ll}\text { April } & \text { July } \\ \text { May } & \text { August } \\ \text { June } & \text { September }\end{array}$

FIgURE 18: The received thermal energy for the Rankine cycle by both the solar field and storage system.

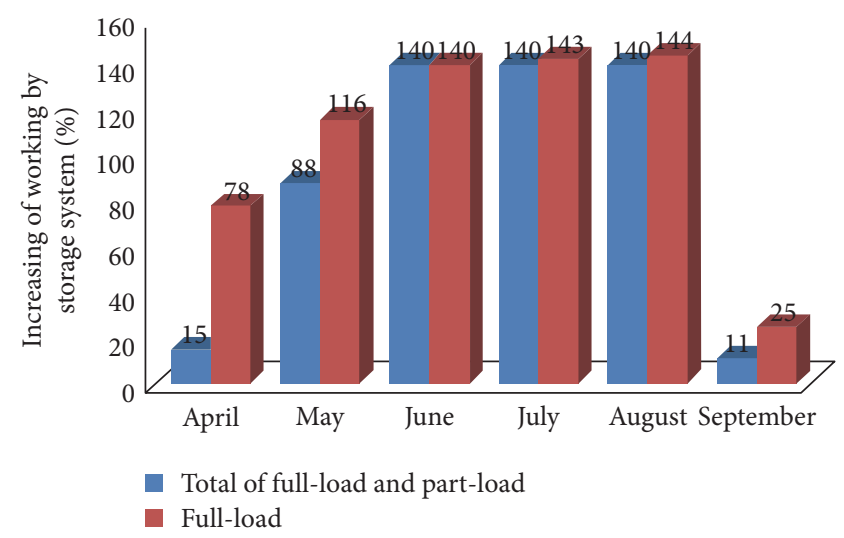

FIgURE 19: Percentage of the operating hour increasing in the solar field by the storage system.

\section{Conclusion}

This article demonstrates a logical methodology for modeling a solar parabolic trough plant which operates at $25 \mathrm{MWe}$ in the Yazd city of Iran. This study has been concentrated on monthly thermal analysis for the solar power plant; then, the influence of the storage system on operating hours has been scrutinized in both full-load and part-load conditions.

In the first step, the trend for calculation of hourly solar beam radiation has been explained. As the study is focused on modeling annual performance in the solar field, it is necessary to determine the heat loss in collectors (convection and radiation). Then, useful thermal power has been surveyed in Figures 3-6 and 8-11. For one year, the solar field provides $3937 \mathrm{GJ}$ useful thermal power by operating near 1726 hours (1248 hours in full-load condition). Figure 13 presents the efficiency of the collector in sunny periods in which the maximum value was achieved in June with $48.5 \%$ 
in average. In Figure 16, the variation of mass flow has been indicated. The analyses show that the mass flow of oil should grow correspondingly to the increment of the solar energy (radiation); consequently, the temperature of heat transfer fluid (oil) not only remained below $400^{\circ} \mathrm{C}$ but also caused efficiency improvement. The remarkable mass flow was attained in June $(11.25 \mathrm{~kg} / \mathrm{s}$ approximately). Next, the model of the storage system in the research has been introduced, two storage tanks where molten salt circles between them as the heat-absorbing liquid. The provided thermal energy for the Rankine cycle and increasing power plant operating time were evaluated. It led to the operating hour increase to 3169 (2785 hours in full-load condition), and the Rankine cycle gained 7974 GJ thermal energy. The storage system operation prompted the power plant to run 24 hours in full-load condition during June and July (Figures 16 and 17).

To nutshell, since the design point is the autumnal equinox (22 September), therefore, solar power plants can gain massive thermal power in sunny periods. The maximum operating time in the solar field is 10 hours per day. The solar power plant starts operating from the middle of March to the end of October, and it is expected to perform at best in June and July.

\section{Nomenclature}

c: $\quad$ Collector concentration ratio (-)

$c p_{\text {oil }}: \quad$ Specific heat capacity of oil $(\mathrm{J} / \mathrm{kg} \cdot \mathrm{K})$

$C_{p, \text { salt }}:$ Specific heat capacity of molten salt $(\mathrm{J} / \mathrm{kg} \cdot \mathrm{K})$

$d_{\mathrm{i}}$ : $\quad$ Inner diameter of a thermal pipe $(\mathrm{cm})$

$d_{\mathrm{o}}$ : Outer diameter of a thermal pipe $(\mathrm{cm})$

$d_{\mathrm{ci}}: \quad$ Inner diameter of a glass cover $(\mathrm{cm})$

$d_{\mathrm{co}}: \quad$ Outer diameter of a glass cover $(\mathrm{cm})$

$F_{r}$ : Collector heat removal factor (-)

$G_{\mathrm{SC}}: \quad$ Solar constant $\left(\mathrm{W} / \mathrm{m}^{2}\right)$

$H$ : Daily radiation inside of the Earth's atmosphere (J/day)

$H_{0}$ : Daily radiation outside of the Earth's atmosphere (J/day)

$h_{\mathrm{p}-\mathrm{c}}:$ Convection heat transfer coefficient between pipe and glass cover $\left(\mathrm{W} / \mathrm{m}^{2} \cdot \mathrm{K}\right)$

$h_{w}$ : Convection heat transfer coefficient between a glass cover and the environment $\left(\mathrm{W} / \mathrm{m}^{2} \cdot \mathrm{K}\right)$

I: Hourly radiation inside of the Earth's atmosphere (J/hour)

$I_{\mathrm{b}}$ : Hourly beam radiation inside of the Earth's atmosphere (J/hour)

$I_{\mathrm{d}}$ : Hourly diffuse radiation inside of the Earth's atmosphere (J/hour)

$I_{0}$ : Hourly radiation outside of the Earth's atmosphere (J/hour)

$K_{T}: \quad$ Rate of air cleanliness (-)

$L: \quad$ Trough length $(\mathrm{m})$

$\dot{m}: \quad$ Oil mass flow $(\mathrm{kg} / \mathrm{s})$

$n: \quad$ Number of day (-)

$q_{1}: \quad$ Lost thermal power $(\mathrm{W})$

$q_{\mathrm{u}}$ : $\quad$ Useful thermal power $(\mathrm{W})$
$S: \quad$ Intensity of solar radiation $\left(\mathrm{W} / \mathrm{m}^{2}\right)$

$T_{\mathrm{a}}: \quad$ Ambient temperature $\left({ }^{\circ} \mathrm{C}\right)$

$T_{c}$ : $\quad$ Glass cover temperature $\left({ }^{\circ} \mathrm{C}\right)$

$T_{\mathrm{fi}}: \quad$ Temperature of oil when entering the array $\left({ }^{\circ} \mathrm{C}\right)$

$T_{\mathrm{fo}}$ : Temperature of oil when leaving the array $\left({ }^{\circ} \mathrm{C}\right)$

$T_{\mathrm{pm}}$ : Average temperature of the pipe surface $\left({ }^{\circ} \mathrm{C}\right)$

$T_{\text {sky }}:$ Temperature of the sky $\left({ }^{\circ} \mathrm{C}\right)$

$U_{L}: \quad$ Heat transfer factor $(\mathrm{W} / \mathrm{m} \cdot \mathrm{K})$

w: $\quad$ Aperture width $(\mathrm{m})$

$\delta: \quad$ Solar declination (degree)

$\varepsilon_{c}: \quad$ Glass cover emissivity (-)

$\varepsilon_{\mathrm{p}}: \quad$ Receiver tube (pipe) emissivity (-)

$\eta_{\text {opt }}:$ Optical efficiency (-)

$\rho_{\text {salt: }}: \quad$ Molten salt density $\left(\mathrm{kg} / \mathrm{m}^{3}\right)$

$\phi: \quad$ Latitude of place (degree)

$\omega: \quad$ Hour angle (degree)

$\omega_{\mathrm{s}}$ : $\quad$ Sunset or sunrise hour angle (degree).

\section{Conflicts of Interest}

The authors declare that there is no conflict of interest regarding the publication of this paper.

\section{References}

[1] U. Pelay, L. Luo, Y. Fan, D. Stitou, and M. Rood, "Thermal energy storage systems for concentrated solar power plants," Renewable and Sustainable Energy Reviews, vol. 79, pp. 82100, 2017.

[2] H. Price, E. Lupfert, D. Kearney, E. Zarza, G. Cohen, and R. Gee, "Advances in parabolic trough solar power technology," Journal of Solar Energy Engineering, vol. 124, pp. 109125, 2002.

[3] K. Ravi Kumar and K. S. Reddy, "Thermal analysis of solar parabolic trough with porous disc receiver," Applied Energy, vol. 86, pp. 1804-1812, 2008.

[4] A. Fernández-García, E. Zara, L. Valenzuela, and M. Perez, "Parabolic-trough solar collectors and their applications," Renewable and Sustainable Energy Reviews, vol. 14, no. 7, pp. 1695-1721, 2010.

[5] S. Relloso and Y. Gutiérrez, "Real application of molten salt thermal storage to obtain high capacity factors in parabolic trough plants," Proceedings of 14th International Solar PACES Symposium on Solar Thermal Concentrating Technologies, 2008, Las Vegas, NV, USA, 2008.

[6] M. J. Montes, A. Abánades, J. M. Martinez-Val, and M. Valdés, "Solar multiple optimization for a solar-only thermal power plant, using oil as heat transfer fluid in the parabolic trough collectors," Solar Energy, vol. 83, pp. 2165-2176, 2009.

[7] J. A. Duffie and W. A. Beckman, Solar Engineering of Thermal Processes, Wiley, New York, NY, USA, 1991.

[8] E. Noorollahi, D. Fadai, M. A. Shirazi, and S. H. Ghodispoor, "Land suitability analysis for solar farms exploitation using GIS and fuzzy analytic hierarchy process (FAHP) - a case study of Iran,” Energies, vol. 9, p. 643, 2016.

[9] V. T. Cheang, R. A. Hedderwick, and C. McGregor, "Benchmarking supercritical carbon dioxide cycles against steam Rankine cycles for concentrated solar power," Solar Energy, vol. 113, pp. 199-211, 2015. 
[10] M. Pidwirny, Fundamentals of Physical Geography, Physical Geography.net, 2nd edition, 2008.

[11] M. Gunther, M. Joemann, and S. Csambor, Parabolic Trough Technology, Chapter: 5. Advanced CSP Teaching Materials, Deutsches Zentrums für Luft- und Raumfahrt e. V.; Institut für Elektrische Energietechnik-Universität Kassel, 2011.

[12] S. P. Sukhatme, Solar Energy: Principles of Thermal Collection and Storage, Tata, MacGraw-Hill, New Delhi, India, 1980.

[13] Z. Yang and S. V. Gurimella, "Thermal analysis of solar thermal energy storage in a molten-salt thermocline," Solar Energy, vol. 84, no. 6, pp. 974-985, 2010.

[14] U. Hermann, B. Kelly, and H. Price, "Two-tank molten salt storage for parabolic trough solar power plant," Energy, vol. 29, pp. 883-893, 2009.

[15] O. Nematollahi, P. Alamdari, and A. A. Alemrajabi, "Monthly mean clearness index for few Iranian cities," 10th International Conference on Sustainable Energy Technologies, 2011, İstanbul, Turkey, 2011. 

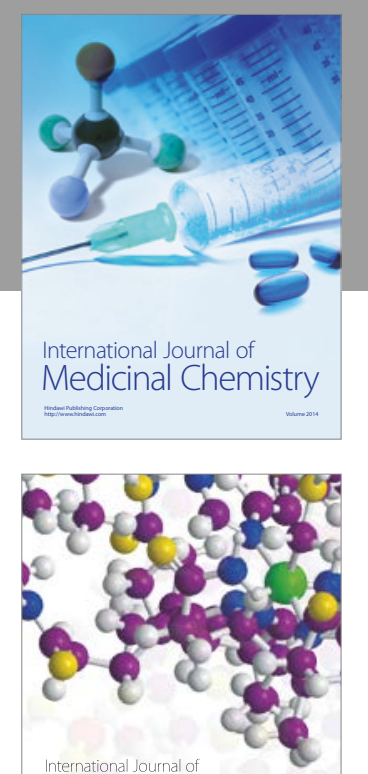

Carbohydrate Chemistry

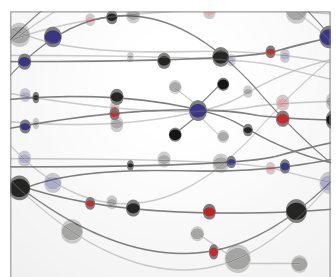

The Scientific World Journal
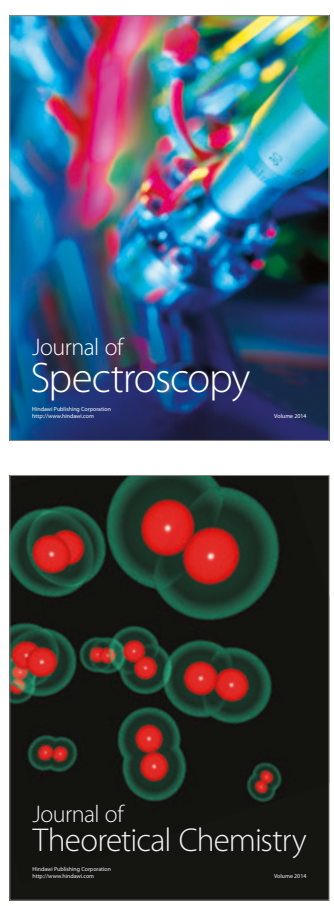
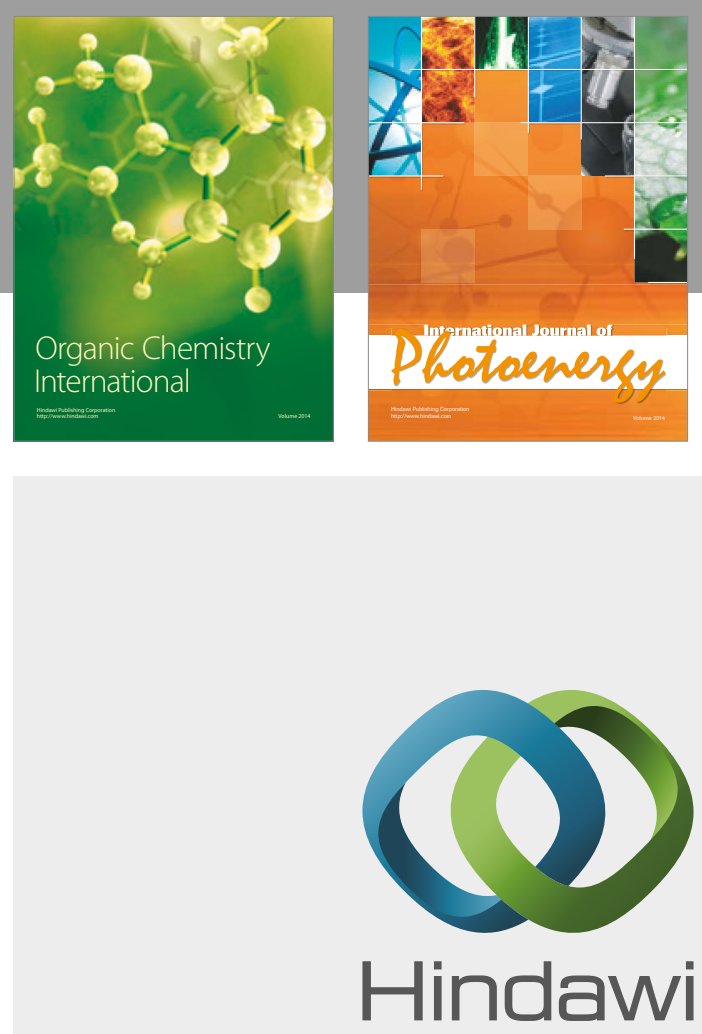

Submit your manuscripts at

https://www.hindawi.com

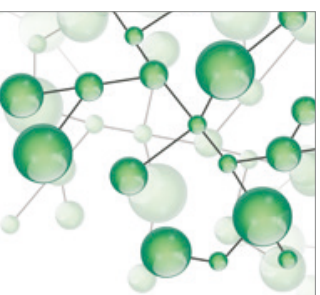

International Journal of

Inorganic Chemistry

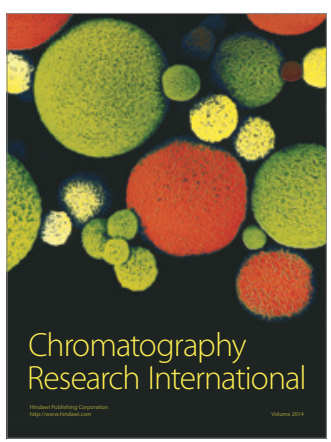

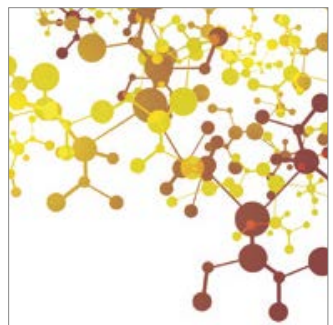

Applied Chemistry
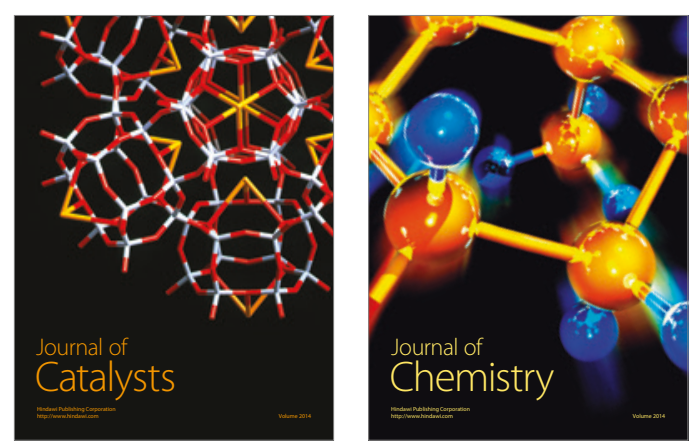
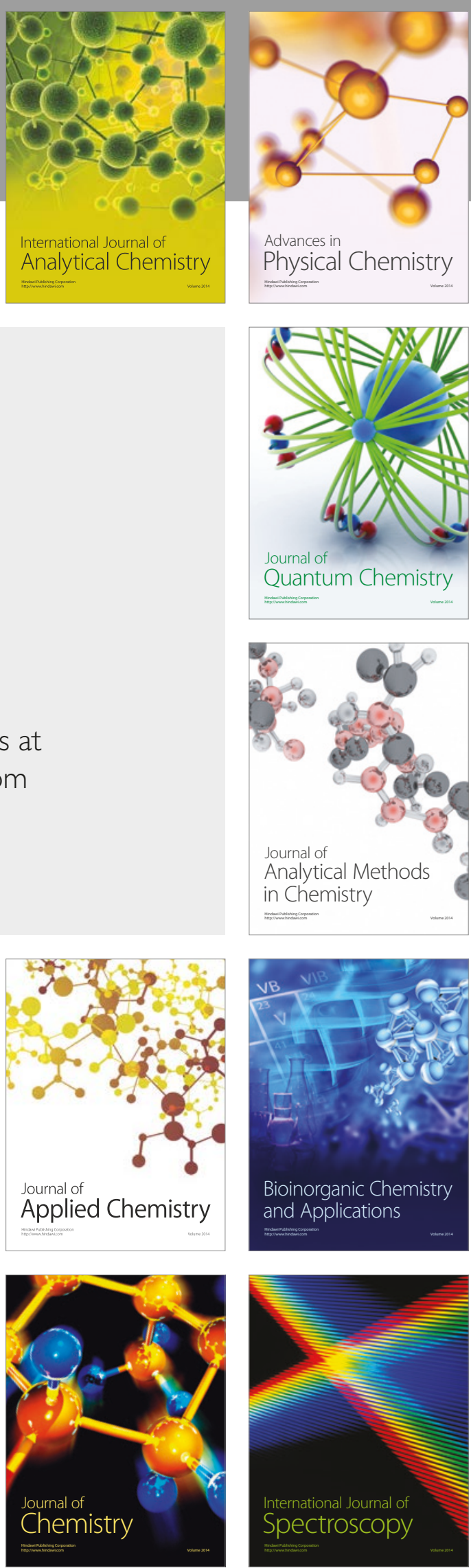